\title{
Empowerment of Family in Early Detection of Total Growth at Puskesmas Karangrejo Metro
}

\author{
Islamiyati Islamiyatia), Sadiman Sadiman and Yoga Triwijayanti \\ Program Studi DIII Kebidanan Metro Poltekkes Kemenkes Tanjungkarang, Lampung, Indonesia \\ Coresponden Author : islamiyati341972@gmail.com
}

\begin{abstract}
The target number of children in early detection of child development and development in the working area of Puskesmas Karangrejo is 1,037 children, with details of 133 infants from $0-11$ months and 904 children aged 12 - 72 months. Of these, the coverage for early detection until February 2020 is still low, namely at $6.7 \%$. The purpose of the Community Service is to empower families in conducting early detection of toddler growth and development in the Karangrejo Health Center area. The method of activity is health education and empowerment of "active participation" of mothers toddler in stimulating and detecting the growth and development of their children. The result of mentoring was that there was progress in the developmental ability of 1 child who had not been able to walk at the age of 19 months, showing an increase in walking ability after 2 weeks of assistance. There was an increase in the knowledge of mothers / families about growth and development by 12.68 points. There was an increase in the frequency of implementing stimulation for child growth and development by mothers of under-five from $88.2 \%$ of mothers who had stimulated to $98.6 \%$ after mentoring. Continuity of family empowerment is needed regarding early detection of growth and development and not only involving mothers / families but also involving cadres.
\end{abstract}

Keywords : Family empowerment, early detection, toddler growth and development

\section{INTRODUCTION}

The target number of children in early detection of child growth and development in the working area of Puskesmas Karangrejo is 1,037 children with details of $0-11$ months babies as many as 133 people and 904 children aged $12-72$ months. Of this amount, the coverage of early detection until February 2020 is still low at $6.7 \%$. The number of posyandu in the Karangrejo Health Center area is 10 posyandu.

The achievement of a child's growth and development is largely determined by the fulfillment of three aspects of the child's basic needs, namely honing, loving and nurturing. Sharpening related to mental stimulation is the forerunner in the learning process (education and training) in children. This sharpening develops psychosocial mentality: intelligence, skills, independence, creativity, religion, personality, moral-ethics, productivity (Soetjiningsih, 2015). Asih is an emotional need or affection. In the first years of life (even in the womb), children absolutely need a close, harmonious and harmonious bond with their mother to ensure the child's physical-mental and psychosocial growth and development. Asuh is a child's needs covering the needs of clothing, food, shelter such as: nutrition, immunization, body and environmental hygiene, clothing, services/health check-ups and treatment, sports, playing and resting. These three aspects of the child's basic needs must be met simultaneously as the child ages.

The process of growth and development of infants and toddlers is an important period in further development. The role of the family in the field of health and social support contributes to toddlers in undergoing a normal and natural growth process so that there are no deviations. The family has 5 functions, namely affective functions, socialization and social placement, health care, reproduction and the economy. The family plays a role and becomes a key actor in determining the right action to address the health problems of family members (Zulaekah, 2014). 
This community service in the form of family assistance aims to increase the knowledge and skills of mothers or families of toddlers in carrying out early detection and stimulation of growth and development, so that children can grow optimally according to their age.

A study conducted by Nair (2009) found that giving early stimulation (at home) in the first year of life, was effective in increasing the index of mental and psychomotor development of infants. Psychosocial interventions at critical developmental stages (under 5 years) can prevent violent behavior in adolescents and adults. Family support in stimulating growth and development in infants and toddlers can improve the process of growth and development. Increasing the role of family and social support (health cadres) also has a positive impact on improving the growth and development process of toddlers (such as: personal social, language and motor skills). Families and health cadres are advised to continue to provide support to infants and toddlers in the family environment and during posyandu activities by providing optimal stimulation (Suryanto, 2014).

\section{MATERIALS AND METHODS}

The materials used for this community service activity are infrastructure facilities that support the learning process so that there is an optimal transformation of knowledge and skills to the target group including: a. Meeting room/hall; b. Extension media/ Learning media: LCD, laptop, loudspeaker, sound system, booklet about stimulation and early detection of growth and development.

The method used in Community Service Activities in the Community Partnership Program (PKM) is to empower families/mothers through health education and mentoring. Health education in general is all planned efforts to influence other people, both individuals, groups and communities so that they do what is expected by health workers.

The officers and implementers of the activities included 3 lecturers of Program Studi Kebidanan Metro, 1 village midwife, 1 coordinator midwife and 6 students of Program Studi Kebidanan Metro. All officers carry out activities on an ongoing basis starting from the division of tasks, implementation and evaluation of activities.

Family empowerment is carried out with a process approach, with the following stages: a. Preparation, including administrative preparation, media preparation, preparation of health workers and community/family preparation b. Implementation, including pre-test, counseling and assistance for 2 months c. Evaluation is carried out after 2 months of mentoring. Analysis of activity results data is descriptive and presented in proportions.

\section{RESULTS}

The results of early detection of toddler growth and development before mentoring, were 31 toddlers with developmental values in accordance with growth and development and 1 toddler with the initials ZT with a KPSP value of 7 has dubious development because a 19month-old child has not been able to walk. After 2 weeks of mentoring the child begins to show progress and at the end of the mentoring the child already has developmental abilities according to his age. While the other 31 children still showed abilities that were appropriate for their age.

Mother's knowledge about stimulation and early detection of child growth and development as measured by a questionnaire with 17 question items obtained a total score of 417 or the average pretest value of 76.65 . The results of the posttest mother's knowledge about stimulation and early detection of child growth and development with a total score of 486 or with an average value of 89.33. Mother's knowledge about stimulation and early detection of child growth and development has increased by 12.68 points after counseling and mentoring to mothers of toddlers about stimulation and early detection of child growth and development is carried out. 
Measurement of stimulation and early detection of child growth and development was carried out by direct observation, both pretest and posttest. Based on the posttest results, it can be seen that there is an increase in the frequency of implementation of child growth stimulation activities by mothers of toddlers from $88.2 \%$ to $98.6 \%$ after mentoring, and among mothers who have been stimulated, there is an increase in mothers who routinely stimulate from $88.6 \%$. to $91.6 \%$. The results of the stimulation and early detection activities can be seen in the attachment table 1.

\section{DISCUSSION}

Community empowerment according to Mardikanto (2003) in (Mardikanto \& Soebiato, 2017 ) is a process of social, economic and political change to empower and strengthen community capabilities through a participatory learning process, so that behavior changes occur in all stakeholders (individuals, groups, institutions) involved in the development process, for the realization of an increasingly empowered, independent and participatory life that is increasingly prosperous in a sustainable manner. Referring to this philosophy, empowerment can be applied by implementing health education.

Efforts to empower families in detecting and stimulating the growth and development of toddlers in the working area of the Karangrejo Health Center are by providing counseling and providing assistance to mothers/families by providing booklets about stimulation and early detection of growth and development of toddlers by providing concrete examples of the implementation of stimulation and early detection to mothers. then the mother/family can do all the activities themselves without being accompanied by a health worker. Research (Morrison et al., 2018) states that in developing countries developmental screening programs are hampered by the low presence of mothers to check the growth and development of their toddlers. In general, mothers of toddlers/caregivers generally do not understand the results of the toddler's growth and development examination. For this reason, health education is needed to increase the knowledge and active behavior of parents in SDIDTK. This is also according to research (Napitupulu, Margaretha Posma Suryani, Aryani \& Vitriani, 2018)

The academic community of Program Studi Kebidanan Metro in this community service acts as a facilitator by using the "active participatory" community empowerment method, namely the Participatory Learning and Practice Method ("Participatory Learning and Action"/PLA), which is a participatory learning method in groups carried out by all stakeholders. interests (stakeholders) interactively in a joint analysis process; reflects several interpretations of problem solving carried out by various parties with different perspectives in an area where decisions are used as a reference for change by the local community (Mardikanto, Totok \& Poerwoko Soebiato, 2017)

\section{CONCLUSIONS AND RECOMMENDATIONS}

The conclusion of Community Service activities in the form of family empowerment in stimulation and early detection of child growth and development in Karangrejo Village, North Metro, Metro City is that the results of early detection of growth and development in one child who doubts are appropriate for their age after mentoring. There was an increase in the knowledge of mothers under five about stimulation and early detection of child development with a total score of 417 (average 75.65) at the pretest, increasing to a total score of 486 (89.33) at the posttest. There was an increase in the frequency of having carried out child development stimulation activities by mothers of toddlers from $88.2 \%$ to $98.6 \%$, with routine implementation from $88.6 \%$ to $91.6 \%$. Providing advice to Program Studi Kebidanan Metro Poltekkes Tanjungkarang need to carry out community service on an ongoing basis. The topic of community service is adjusted to the problem. Suggestions to Puskesmas Karangrejo need to follow up on Community Service in the form of family empowerment regarding stimulation and early detection of child growth and development

\section{ACKNOWLEDGMENTS}


We thank God for the presence of Allah Subhanahu Wa Ta'ala, for His mercy and grace so that this Community Service can run smoothly. We also extend our gratitude to the Director of Poltekkes Tanjungkarang and his staff, the Metro City Health Office, the Head of Karangrejo Health Center and its equipment, the Head of the Metro Midwifery DIII Study Program and all parties who helped carry out this Community Service activity.

\section{REFERENCES}

Christiyawati M.D. 2016. Pemberdayaan Keluarga untuk Stimulasi Tumbuh Kembang \& Kecerdasan Anak TK Usia 4-6 tahun di TK Islam Bakti Sobokerto Ngemplak Boyolali. www.poltekkessolo.ac.id

Hasanah T, Sunarti E, Krisnatuti D. 2014. Pengaruh Pemberdayaan Keluarga Terhadap Peningkatan Pengetahuan Ibu Mengenai Pengasuhan Anak Usia Prasekolah. Jurnal IImiah

Hermaningsih S dan Iryanti. 2016. Pemberdayaan Keluarga dalam Stimulasi, Deteksi, dan Intervensi Dini Tumbuh Kembang Anak 1-3 Tahun Melalui Pembelajaran Modul di RW-05 Kelurahan Kujangsari Kecamatan Bandung Kidul. Jurnal Kesehatan Kartika Vol. 11 No.2

Kemenkes RI. 2012. Pedoman Pelaksanaan Stimulasi, Deteksi Dini dan Intervensi Dini Tumbuh Kembang Anak di Tingkat Pelayanan Kesehatan Dasar, Dirjen Bina Kesmas. Jakarta

Mardikanto, T \& Soebiato P, 2017. Pemberdayaan Masyarakat dalam Perspektif Kebijakan Publik. Cetakan ke-4, PT. Alfabeta, Bandung.

Napitupulu, Margaretha Posma Suryani, Aryani \& Vitriani, 2018. Faktor-Faktor yang Berhubungan dengan Sikap Kader Posyandu dalam Melakukan Deteksi Dini Perkembangan Bayi/Balita di Wilayah Kerja Puskesmas Rumbai Kota Pekanbaru Tahun 2017, Jurnal Ibu dan Anak Volume 6, Nomor 1, Jurusan Kebidanan Poltekkes Kemenkes Riau.

Rahmawati I. 2019. Pendampingan Ibu dalam Stimulasi Perkembangan Motorik untuk Mengoptimalkan Perkembangan Balita di Desa Mayong Lor Kecamatan Mayong Kabupaten Jepara. Jurnal Pengabdian Masyarakat Amaliah. Vol. 3 No 1. Mei 2019

Soetjiningsih dan Ranuh IG.N.G, 2015, Tumbuh Kembang Anak, Edisi 2, EGC, Jakarta

Sulistyawati A, Amalia D.A, Anggraini N.A. 2019. Pemberdayaan Keluarga dalam Deteksi dan Stimulasi Tumbuh Kembang Balita. Jurnal Abdimas Madani Vol. 1 No. 1 Januari 2019.

Sunanti F dan Nurasih. 2016. Karakteristik Orang Tua dan Perkembangan Balita Usia 12 - 59 bulan. Jurnal Care No. 4 Vol. 3 tahun 2016

Suryanto, Purwandari H, Mulyono W.A. 2014. Dukungan Keluarga dan Sosial dalam Pertumbuhan dan Perkembangan Personal Sosial, Bahasa dan Motorik pad Balita di Kabupaten Banyumas. Jurnal Kesehatan Masyarakat Vol. 10 No 12014.

Zulaekah S. dkk. 2014. Anemia terhadap Pertumbuhan dan Perkembangan Anak Malnutrisi. Jurnal Kesehatan Masyarakat Vol. 9 No 2 


\section{ATTACHMENT}

Table 1. Results of Activities Stimulation and early detection of growth and development of toddlers

\begin{tabular}{|l|c|c|c|c|}
\multirow{2}{*}{ Category } & \multicolumn{2}{c|}{ Pretes } & \multicolumn{2}{c|}{ Postest } \\
\cline { 2 - 5 } & Total & $\%$ & Total & $\%$ \\
\hline Frequency: & & & & \\
\hline 1. Once & 246 & 88,2 & 275 & 98,6 \\
\hline 2. Never & 33 & 11,8 & 4 & 1,4 \\
\hline \multicolumn{1}{|c|}{ Amount } & 279 & 100 & 279 & 100 \\
\hline Consistency: & & & & \\
\hline 1. Routine & 218 & 88,6 & 252 & 91,6 \\
\hline $\begin{array}{l}\text { 2. Not } \begin{array}{l}\text { Routine } \\
\text { Amount }\end{array} \\
\text { Amyyyy}\end{array}$ & 28 & 11,4 & 23 & 8,4 \\
\hline
\end{tabular}

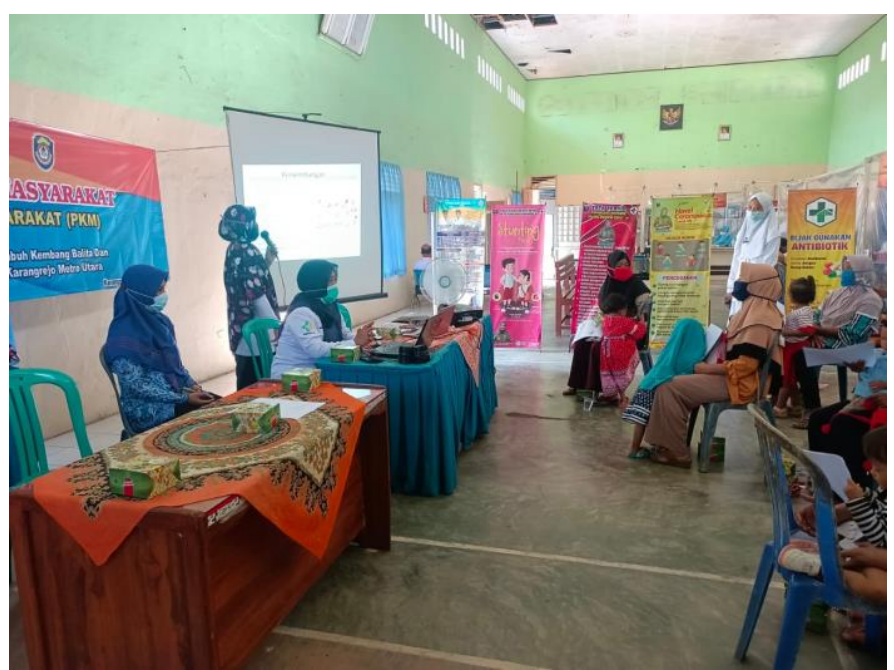

Figure 1. Extension activities before mentoring

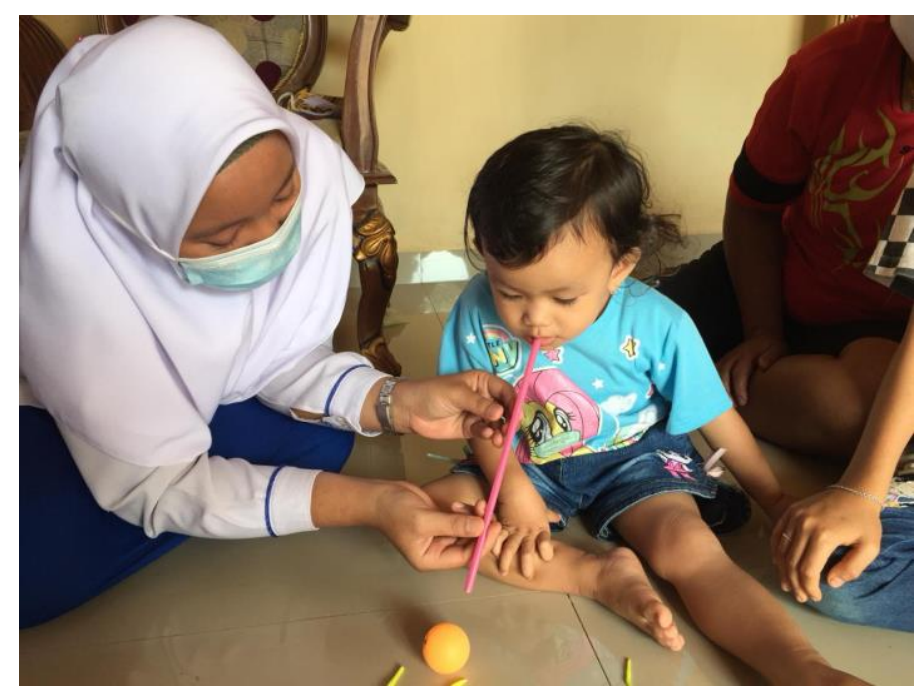

Figure 2. Assistance activities for families 